\title{
Performance of prothioconazole solo or added to mancozeb in the control of Asian soybean rust
}

\author{
Erlei Melo Reis ${ }^{1} \mathbb{0}$, Mateus $Z_{\text {Zanatta }}^{2} \oplus$, Andrea Camargo Reis ${ }^{2}(\mathbb{0}$
}

${ }^{1}$ Universidad de Buenos Aires, Facultad de Agronomía, Escuela para Graduados, Buenos Aires, Argentina; ${ }^{2}$ Instituto Agris, Passo Fundo, RS, Brasil

Autor para correspondência: Erlei Melo Reis (erleireis@upf.br)

Data de chegada: 15/01/2018. Aceito para publicação em: 28/11/2019.

$10.1590 / 0100-5405 / 190162$

\section{ABSTRACT}

Reis, E.M.; Zanatta, M.; Reis, A.C. Performance of prothioconazole solo or added to mancozeb in the control of Asian soybean rust. Summa Phytopathologica, v.46, n.4, p.345-347, 2020.

The evolution of the reduction in Asian soybean rust (caused by Phakopsora pachyrhizi) control by site-specific fungicides has been reported season after season. In a field experiment, the effect of prothioconazole solo and added to multisite mancozeb was evaluated for rust control. Treatments were evaluated in a factorial design of four prothioconazole doses and three mancozeb doses. In a set of treatments, three applications were performed in one soybean cycle and four applications in another one. The first applications were performed at GS V8, 11 days before rust detection, with $2.56 \%$ leaflet incidence, while the other applications were at 12 to 14-day interval. Rust severity was quantified, control was calculated in relation to the unsprayed treatment, and soybean grain yield was estimated as $\mathrm{kg} / \mathrm{ha}$. Fifty-one to $61 \%$ control was obtained with three sprayings and $68 \%$ to $70 \%$ control with four sprayings of prothioconazole alone. Over $80 \%$ control was obtained with at least $0.3 \mathrm{~L} /$ ha prothioconazole $+2.0 \mathrm{~kg} / \mathrm{ha}$ mancozeb, corresponding to $75 \mathrm{~g}$ a.i./ha prothioconazole $+1500 \mathrm{~g}$ a.i./ha mancozeb. Reduction in P. pachyrhizi control by the use of the site-specific fungicide alone was confirmed, while the addition of mancozeb can recover the efficacy of the site-specific fungicide.

Keywords: Chemical control, Glycine max, Phakopsora pachyrhizi, fungicide resistance, triazolinedione.

\section{RESUMO}

Reis, E.M.; Zanatta, M.; Reis, A.C. Desempenho do protioconazol isolado ou adicionado ao mancozebe no controle da ferrugem asiática da soja. Summa Phytopathologica, v.46, n.4, p.345-347, 2020.

Tem sido relatada a evolução da redução do controle da ferrugem asiática da soja causada por Phakopsora pachyrhizi pelos fungicidas sítio-específicos safra após safra. Em experimento conduzido no campo, foi avaliado o efeito do protioconazol isolado e adicionado ao multissítio mancozebe no controle da ferrugem. Os tratamentos foram avaliados em delineamento fatorial de quatro doses do protioconazol e três doses do mancozebe. Num grupo de tratamentos foram feitas três aplicações no ciclo da soja e em outro quatro. As primeiras aplicações foram realizadas no estádio GS V8, 11 dias antes da detecção da ferrugem com 2,56\% de incidência foliolar e as demais aos com 12 a 14 dias de intervalo. A severidade da ferrugem foi quantificada, o controle calculado em relação ao tratamento sem aplicação e o rendimento de grãos estimado em kg/ha. Cinquenta e um a $61 \%$ de controle foi obtido com três aplicações e 68 a $70 \%$ com quatro aplicações de protioconazol isolado. Controle superior a $80 \%$ foi obtido com no mínimo $0,3 \mathrm{~L} /$ ha de protioconazol $+2,0 \mathrm{~kg} / \mathrm{ha}$ mancozebe, correspondendo a $75 \mathrm{~g}$ i.a./ha de protioconazol $+1500 \mathrm{~g}$ i.a./ha de mancozebe. A redução do controle de P. pachyrhizi pelo uso isolado do fungicida sítio-específico foi confirmada e a adição do mancozebe pode recuperar a eficácia do sítio-específico.

Palavras-chave: Controle químico, Glycine max, Phakopsora pachyrhizi, resistência a fungicidas, triazolintiona.

Soybean [Glycine $\max (\mathrm{L}$.$) Merr.] growing area in Brazil has$ increased season after season, reaching 35.8 million hectares in the 2018/19 season (2).

Since the 2002/03 season, Asian Soybean Rust (ASR) control has employed only site-specific fungicides: (i) triazoles or inhibitors of cell membrane synthesis, (ii) strobilurins and more recently another class of chemicals, (iii) carboxamides or respiration inhibitors (7). After five seasons of use of site-specific chemicals alone, such as demethylation inhibitors (DMIs), a reduction has been reported in $P$. pachyrhizi sensitivity to these chemicals $(6,7,10)$. In the following seasons, ready-mix site-specific co-formulations of DMIs + quinone outside inhibitors (QoIs) or QoIs + succinate dehydrogenase inhibitor (SDHI) were used. Among the three groups (DMI, QoI and SDHI) of site-specific fungicides, prothioconazole (Prot), a DMI released to the market in the 2012/13 season in combination with trifloxystrobin, has been the most efficient and thus the most used fungicide for rust control in the 2016/17 season (7).

The hypothesis raised in this study is that the efficacy of the site-specific fungicides available in the market is not greater than $68 \%$ for ASR control. Thus, the anti-resistance strategy (addition of a multisite fungicide to a site-specific fungicide) used to control late blight (Phytophthora infestans De Bary) in tomato and potato, as well as downy mildew (Plasmopara viticola De Toni), may also be a useful tool to recover the effectiveness of these three MOA to fight $P$. pachyrhizi, especially prothioconazole.

The objective of this study was to evaluate the actual efficacy of 
prothioconazole, a site-specific fungicide, solo and added to mancozeb, in the control of P. pachyrhizi in the soybean crop.

The experiment was conducted in the Webber Seeds Farm, Coxilha County, Rio Grande do Sul State (28 09'33.8"S latitude, $52^{\circ} 18^{\prime} 20.1$ ' W longitude, and $710 \mathrm{~m}$ a.s.1.) in the 2016/17 growing season. The used soybean cultivar was 'DuPont Pioneer 96Y90-RR', sown on December $7^{\text {th }}, 2016$, and under soybean monoculture.

Treatments were conducted according to a factorial design with four Prot (Proline $250 \mathrm{~g} / \mathrm{L} \mathrm{SC}$ ) doses $(0.3,0.4,0.5,0.6 \mathrm{~L} / \mathrm{ha}$ ) added to three mancozeb doses $(0.0,2.0,3.0 \mathrm{~kg} / \mathrm{ha})$ (Unizeb Gold $750 \mathrm{WG}$ ) and an unsprayed treatment. Plots were arranged in a randomized complete block design with four replicates.

Fungicides were applied with a $\mathrm{CO}_{2}$ pressurized backpack sprayer equipped with Hypro ${ }^{\circledR}$ LD $015 \mathrm{~F} 110$ nozzles spaced at $0.5 \mathrm{~m}$ and delivering $150 \mathrm{~L} /$ ha water.

Foliolar ASR severity was estimated per plot, according to a diagrammatic scale for ASR severity evaluation proposed by Godoy et al. (5).

The first fungicide application was performed on February $2^{\text {nd }}$, 2017, at GS V8, and rust was detected after 11 days, on February $13^{\text {th }}$, 2017 , with $2.56 \%$ leaflet incidence which was, therefore, below the economic damage threshold (LDE). The LDE, calculated according to Danelli et al. (3), was 16\% leaflet incidence (LI).

Regarding the control for three solo Prot applications, general mean was $57 \%$, not reaching the minimum control of $80 \%$ for maximum yield (8).

There was an increase from $74 \%$ to $78 \%$ for 2.0 and $3.0 \mathrm{~kg} / \mathrm{ha}$ mancozeb doses, respectively. The increasing Prot doses resulted in $65 \%, 69 \%, 73 \%$ and $72 \%$ control, respectively (Table 1 ).

Considering four sprayings, control with Prot solo was $69 \%$. According to the mancozeb doses, four sprayings led to $88 \%$ to $89 \%$ control with the addition of 2.0 and $3.0 \mathrm{~kg}$ mancozeb, respectively. Prot control increased from $77 \%, 85 \%, 83 \%$ to $83 \%$ with increasing doses, respectively (Table 1).

Regardless of the Prot dose, the highest control, $88 \%$ and $89 \%$, was obtained with the addition of 2.0 or $3.0 \mathrm{~kg} / \mathrm{ha}$ mancozeb, first application performed with $2.75 \% \mathrm{LI}$ and four applications with a 12-14-day interval.

Plant defoliation was not evaluated because it is a function of severity, as demonstrated with the positive relationship between severity and defoliation caused by ASR (8).

Soybean grain yield, considering three applications in the treatment with Prot solo, was 4,397 kg/ha. For 2.0 and $3.0 \mathrm{~kg} /$ ha mancozeb doses, the yield increased from 4,397 (Prot solo) and 4,810 to $4,857 \mathrm{~kg} / \mathrm{ha}$, respectively. For Prot doses, soybean grain yield increased from 4,497, $4,660,4,668$ to $4,916 \mathrm{~kg} / \mathrm{ha}$, respectively (Table 2).

Analyzing the effect of four applications, there were no differences in grain yield for Prot doses ranging from 5,244, 5,449, 5,550 to 5,569 $\mathrm{kg} / \mathrm{ha}$. However, for $0,2.0$ and $3.0 \mathrm{~kg} / \mathrm{ha}$ mancozeb addition, grain yield increased from zero, 5,119 to 5,550 and $5,569 \mathrm{~kg} / \mathrm{ha}$, respectively. Addition of $2.0 \mathrm{~kg}$ mancozeb to Prot resulted in a $431 \mathrm{~kg} / \mathrm{ha}$ increase in grain yield (Table 2).

Considering the reduction in P. pachyrhizi sensitivity to DMIs and QoIs $(1,6,9,10)$, Prot co-formulation with trifloxystrobin (Trif), still the best option at the present, is under high directional selection pressure due to their use without multi-site MOA for ASR control. The present data confirm a gradual reduction in Prot efficacy, season after season, which needs the earliest possible addition of a multisite fungicide to maintain its longer effective life $(1,6,7)$.
Table 1. Effect of prothioconazole (Prot) doses added to mancozeb doses on the control of Asian soybean rust severity (\%) with three and four sprayings

\begin{tabular}{llllll}
\hline Three sprayings & \multicolumn{5}{l}{ Mean } \\
\hline \multirow{2}{*}{ Prot dose (L/ha) } & \multicolumn{5}{l}{ Mancozeb (kg/ha) } \\
\cline { 2 - 5 } & 0.0 & 2.0 & 3.0 & & \\
\hline 0.3 & 51 & 70 & 75 & 65 & $\mathrm{c}$ \\
0.4 & 57 & 71 & 78 & 69 & $\mathrm{bc}$ \\
0.5 & 60 & 79 & 81 & 73 & $\mathrm{a}$ \\
0.6 & 61 & 76 & 78 & 72 & $\mathrm{ab}$ \\
\hline Mean & C 57 & B 74 & A 78 & & \\
\hline Four sprayings & & & & & \\
\hline 0.3 & 68 & 81 & 82 & 77 & $\mathrm{~b}$ \\
0.4 & 69 & 92 & 93 & 85 & $\mathrm{a}$ \\
0.5 & 69 & 90 & 91 & 83 & $\mathrm{a}$ \\
0.6 & 70 & 90 & 88 & 83 & $\mathrm{a}$ \\
\hline Mean & B 69 & A 88 & A 89 & & \\
\hline
\end{tabular}

Means followed by the same lowercase letter in the columns and uppercase letters on the lines are not different, according to Tukey's test at 0.05 . Severity in unsprayed plots: $70 \%$.

Table 2. Effect of prothioconazole (Prot) doses added to mancozeb doses on soybean grain yield $(\mathrm{Kg} / \mathrm{ha})$ to control Asian soybean rust with three and four sprayings

\begin{tabular}{|c|c|c|c|c|c|c|c|c|}
\hline \multicolumn{9}{|l|}{ Three sprayings } \\
\hline \multirow{2}{*}{ Prot doses (L/ha) } & & \multicolumn{5}{|c|}{ Mancozeb doses (kg/ha) } & \multirow{2}{*}{\multicolumn{2}{|c|}{ Mean }} \\
\hline & & 0.0 & & 2.0 & & 3.0 & & \\
\hline 0.3 & & 4224 & & 4611 & & 4656 & 4497 & $\mathrm{~b}$ \\
\hline 0.4 & & 4410 & & 4751 & & 4820 & 4660 & $\mathrm{ab}$ \\
\hline 0.5 & & 4442 & & 4760 & & 4831 & 4678 & $\mathrm{ab}$ \\
\hline 0.6 & & 4510 & & 5118 & & 5120 & 4916 & a \\
\hline Mean & B & 4397 & A & 4810 & A & 4857 & & \\
\hline \multicolumn{9}{|l|}{ Four sprayings } \\
\hline 0.3 & & 5087 & & 5333 & & 5313 & 5244 & a \\
\hline 0.4 & & 5096 & & 5676 & & 5721 & 5498 & a \\
\hline 0.5 & & 5126 & & 5587 & & 5636 & 5450 & a \\
\hline 0.6 & & 5167 & & 5606 & & 5606 & 5459 & a \\
\hline Mean & B & 5119 & A & 5550 & A & 5569 & & \\
\hline
\end{tabular}

Means followed by the same lowercase letter in the columns and uppercase letters in the lines are not different, according to Tukey's test at 0.05 . Gain yield of unsprayed plots: $3156 \mathrm{Kg} / \mathrm{ha}$.

Recently, Braga et al. (1) reported that the sensitivity reduction factor of 17 P. pachyrhizi isolates to prothioconazole ranged from 1.25 to 26 , confirming the sensitivity reduction.

A triple co-formulation containing Prot + Trif + mancozeb applied to the whole soybean area in all sprayings is likely to reduce $P$. pachyrhizi directional selection towards resistance. On the contrary, the increase in the treated area and number of sprayings/area/season, without the addition of a multisite fungicide, could accelerate the reduction in the effective life of Prot, currently considered the most powerful fungicide against $P$. pachyrhizi. Similarly, Prot + Trif and 
QoI + SDHI co-formulations and others do not comply with FRAC (4) recommendations since they are not individually efficient for rust control $(>80 \%)$.

Regarding the reduction in $P$. pachyrhizi sensitivity towards DMIs, QoIs and SDHIs, even solo or in double or triple mixtures, the present results suggest the development, as early as possible, of ready liquid co-formulation containing prothioconazole + mancozeb, or prothioconazole + trifloxystrobin + mancozeb, in compliance with FRAC recommendations regarding the fungicide resistance strategy against fungi to keep their effective life the longest possible (4)

\section{REFERENCES}

1. Braga, K. Fantin, L.H.; Minchio, C.A.; Scolin, L.B.; Paduan, F.N.; Canteri, M.G. Sensibilidade de populações de Phakopsora pachyrhizi ao fungicida protioconazol. Summa Phytopathologica, v.46, n.2, p.150-154, 2020.

2. Conab. Acompanhamento da safra brasileira: grãos, Brasília, DF, v. 2, V.7 - Safra 2019/20, Primeiro levantamento. Outubro 2019. ISSN 2318-6852. Disponível em: https://www.conab.gov.br/info-agro/safras/graos/boletim-da-safra-de-graos?limitstart=0. Acesso em: 16 janeiro 2020.
3. Danelli, A.L.D.; Reis, E.M.; Boaretto, C. Critical-point model to estimate yield loss caused by Asian soybean rust. Summa Phytopathologica, Botucatu, v.41, n.4, p.262-269, 2015.

4. Fungicide Action Committee. Update EPPO Resistance Panel Berlin, 19 September 2017.

5. Godoy, C.V., Koga, L.J.; Canteri, M.G. Diagrammatic scale for assessment of soybean rust severity. Fitopatologia Brasileira, Brasília, DF, 31:063068. 2006.

6. Reis, E. M.; Deuner, E.; Zanatta, M. In vivo sensitivity of Phakopsora pachyrhizi to DMI and QoI fungicides. Summa Phytopathologica, Botucatu, v. 41, n. 1, p. 21-24, 2015

7. Reis, E.M.; Reis, A. C.; Zanatta, M.; Silva, L. H. C. P; Siqueri, F. V.; Silva, J. R. C. Evolução da redução da sensibilidade de Phakopsora pachyrhizi a fungicidas e estratégia para recuperar a eficiência do controle. 3. ed., rev. e ampl. - Passo Fundo: Berthier. 2017. 104 p.

8. Reis, E.M.; Zanatta, M.; Reis, A.C. Relationship between soybean plant defoliation and Asian soybean rust severity. Summa Phytopathologica, Botucatu, v.45, n.3, p.252-254, 2019.

9. Reis, E.M.; Zanatta, M.; Reis, A.C. Eficiência do controle de doenças para igualar ao custo da aplicação terrestre de fungicida. Summa Phytopathologica, Botucatu, 2018 (in press).

10. Xavier, S.A.; Koga, L.J.; Barros, D.C.M.; Canteri, M.G.; Lopes, I.O.N.; Godoy, C.V. Variação da sensibilidade de populações de Phakopsora pachyrhizi a fungicidas inibidores da desmetilação no Brasil. Summa Phytopathologica, Botucatu, v. 41, n. 3, p. 191-196, 2015. 